ljtihad, Jurnal Wacana Hukum Islam dan Kemanusiaan

Vol. 18, No. 1 (2018), pp. 81-98, doi : 10.18326/ijtihad.v18i1.81-98

\title{
Paradigma baru fiqih perdagangan bebas: Dialektika ulüm al-din dan hukum negara
}

\author{
Akmal Bashori \\ Fakultas Syariah dan Hukum UNSIQ Wonosobo Jawa Tengah \\ E-mail: akmalbashori@gmail.com \\ DOI: $10.18326 /$ ijtihad.v18i1.81-98
}

The people of the world (Muslim) enter a new era where between free countries do trade relations without any customs duties, this is called free trade. Everything is governed by market players who have strong capital, rooted in the concept of capitalism. Although Islam advocates seeking as much treasure as you live forever, however, Islam does care about each other. With the advent of free trade, what should the Indonesian state do? Do you have to sacrifice the withdrawal of customs levy which has been the country's income? How does Islam see this? What is the concept that offer fiqih about free trade? The key problem must be between the science of religion with the state so that the policies taken by the state bring maslahat to millions of Indonesian people.

Masyarakat dunia (muslim) memasuki era baru dimana antara negara bebas melakukan hubungan dagang tanpa ada pungutan bea cukai. Inilah yang disebut perdagangan bebas. Semuanya diatur oleh pelaku pasar yang mempunyai modal kuat, berakar dari konsep kapitalisme. Meskipun Islam menganjurkan mencari harta sebanyak-banyaknya seperti halnya engkau hidup selamanya, namun Islam sangat mempedulikan sesamanya. Dengan munculnya gagasan perdagangan bebas maka apa yang harus dilakukan negara Indonesia? Apakah harus mengorbankan penarikan retribusi bea cukai yang selama ini menjadi pemasukan negara? Bagaimana pula Islam memandang hal ini? Apa konsep yang ditawarkan fiqih mengenai perdagangan bebas? Kunci permasalahan tersebut harus mengawinkan antara ilmu agama dengan negara agar kebijakan yang diambil oleh negara membawa maslahat bagi jutaan umat Indonesia.

Keywords: Free market; Fiqh; State; Maslahah

\section{Pendahuluan}

Akhir-akhir ini, publik digegerkan dengan munculnya Masyarakat Ekonomi Asean (MEA), yang arahnya kepada perdagangan bebas. Jika kita melihat konteks sejarah ekonomi klasik, 
ljtihad: Jurnal Wacana Hukum Islam dan Kemanusiaan, Volume 18, No. 1, Juni 2018: 81-98

maka terdapat paradigma ekonomi yang menimbulkan pertentangan hebat yang berakar pada dua pandangan ekstrim. Pertama, mainstream yang menganggap sarana-sarana produksi dan distribusi dimiliki oleh individu secara bebas. Barang dan jasa diperdagangkan di pasar bebas (free market) yang bersifat kompetitif dan modal (capital) baik uang maupun kekayaan lain diinvestasikan ke dalam berbagai usaha untuk menghasilkan laba (profit). Kelompok ini di pandegani oleh kapitalisme. Kedua, mainstream yang menganggap sarana-sarana produksi dan distribusi harus dilakukan dengan tindakan otoritas demokratisasi terpusat untuk menjamin kemakmuran bersama. Kelompok ini di pandegani oleh sosialisme.

Namun, pada prinsipnya bahwa perdagangan bebas dan pasar bebas merupakan alat yang digunakan oleh negara-negara maju untuk kepentingan ekonominya. Dengan perdagangan bebas dan pasar bebas, pasar dunia akan terbuka sehingga segala bentuk proteksi termasuk yang sifatnya menjaga keutuhan ekonomi dalam negeri suatu negara menjadi hilang, akibatnya negara-negara yang tidak mampu bersaing dalam hal ini negara-negara berkembang dan miskin menjadi korbannya. Daya saing menjadi lemah, potensi ekonomi malah tersedot ke negara-negara maju, harga diri dengan mudah diinjak-injak, ujungnya ketidakadilan yang dialami.

Semua itu merupakan strategi Amerika untuk menguasai ekonomi dunia, tidak hanya negara-negara berkembang dan miskin tetapi juga negara-negara maju yang menjadi pesaing Amerika akan dilibas dan digulung ke dalam genggaman Amerika. Tidak lain perdagangan bebas dan pasar bebas hanyalah merupakan metode penjajahan gaya baru, yakni new imperialisme di bidang ekonomi. Jelas perdagangan bebas dan pasar bebas sangat berbahaya terutama bagi dunia ketiga, dan bertentangan dengan sistem ekonomi Islam.

Islam sebagai agama paripurna, memiliki perhatian serius terhadap dinamika sosial ekonomi di atas. Sebab aktivitas sosial ekonomi merupakan salah satu dari enam asas primer kehidupan (al-mabādi' as-sittab), yang menjadi cita-cita Islam (maqāsid asy-syarì'ah), di mana Islam hadir untuk melindunginya. Yakni, perlindungan agama ( $h i f_{z}$ ad-din), perlindungan jiwa (bif乏an-nafs), perlindungan kebebasan intelektual (bifzal-'aqh), perlindungan garis genealogi (bifzan-nash), perlindungan properti (bif zal-māh), dan perlindungan martabat (bifzal-ird).

Proyek dari perhatian serius yang diberikan Islam terhadap aktivitas sosial-ekonomi melalui legislasi konsep-konsep interaksi sosial dalam khazanah fiqih, adalah dalam kerangka 
memberikan penjagaan dan perlindungan terhadap asas-asas primer kehidupan tersebut, agar memungkinkan terciptanya kemaslahatan semesta (rahmatan lil ālamîn). Esensi dari konsep sosial-ekonomi (mu'ämalat) yang ditawarkan Islam, yang berorientasi pada kalkulasi untung rugi belaka -seperti esensi yang ditawarkan kapitalisme- yang melahirkan kesenjangan sosial-ekonomi.

Konsep interaksi sosial ekonomi yang diperjuangkan Islam adalah konsep kehidupan yang manusiawi, berorientasi kepada nilai-nilai kemaslahatan dan keadilan. Karena itu Islam tidak melegalkan praktik riba (interes) yang menindas, praktik manipulasi (gharar), spekulasi (majhül) tidak jelas, dan praktik perjudian (qimār) yang kotor. Islam melandaskan legalitas setiap transaksi, berdasar asas saling rela (tarädin) dan dengan hati yang legawa (tib an-nafs).

Berdasarkan uraian di atas, kita melihat terdapat pertentangan antara ketiga mainstream besar ekonomi: kapitalistik, sosialistik dan Islamis. Dari hal tersebut maka timbul permasalahan, karena Islam sangat menentang monopoli harta hanya pada segelintir orang, maka yang terjadi Islam via a vis kapitalis selalu resisten. Dari permasalah besar itu maka dalam tulisan ini akan mengkaji; pertama, bagaimana pandangan fiqih tentang bea cukai khususnya kasus di Indonesia? di dalamnya memuat; status hukum barang selundupan, dan hukum retribusi bea cukai. Kedua, bagaimana konsepsi fiqih merespon pasar bebas? Di dalamnya memuat stategi menghadapi pasar global tersebut.

\section{Paradigma fiqih perdagangan bebas}

Sekitar satu setengah dekade yang lalu, tepatnya 4 mei 2003 Universitas Jember Jawa Timur menyelanggarakan seminar nasional dengan tema "Paradigma Fiqih Penyebab Keterpurukan Indonesia”. Seminar yang cukup menyita perhatian masyarakat luas waktu itu, khususnya kalangan pesantren. Jika Imam al-Ghazali dengan ajaran tasawufnya dituduh sebagai orang yang membunuh ayam yang sedang bertelur emas, maka dalam seminar tersebut fiqih dianggap sebagai biang keladi keterbelakangan umat. Disinyalir umat dan para ulama banyak menghabiskan waktu untuk membahas persoalan fiqih, dan seringkali berseturu serta bertengkar karenanya. Lalu, benarkah anggapan demikian?

Sepanjang perjalanan sejarahnya, dengan berkembangnya Islam ke berbagai penjuru dunia dan digandrunginya Islam oleh pluralitas suku bangsa, maka kebutuhan untuk menyusun 
ljtihad: Jurnal Wacana Hukum Islam dan Kemanusiaan, Volume 18, No. 1, Juni 2018: 81-98

doktrin Islam yang bersifat standar menjadi mendesak. Oleh karenanya, di antara jasa besar yang dilakukan oleh para imam ahli fiqih (dan cabang ilmu keislaman lainnya) adalah prestasi mereka dalam melakukan formulasi fiqih Islam, sehingga memudahkan para kiai masyarakat umum untuk mencari rujukan agama. Pertanyaan-nya, mengapa ilmu fiqih begitu penting dan paling menonjol di masyarakat Islam?

Barang kali ada beberapa alasan, pertama, Islam memiliki ajaran yang menuntut tindakan praktis berkenaan dengan norma perilaku dan aturan peribadatan yang secara lahiriah harus diukur. Untuk itu, posisi ilmu fiqih dalam Islam menjadi sangat vital karena secara lahiriah atribut seorang muslim bisa diukur dengan aturan fiqih. Kedua, dengan berkembangnya jumlah umat Islam yang begitu cepat, dan pada abad tengah dunia Islam merupakan masyarakat paling makmur di dunia, maka lahirlah sebuah kebutuhan bagi ulama dan umara untuk mengendalikan atau membimbing umat dalam perilaku sosial dan politik, sehingga dengan demikian ilmu fiqih sangat menonjol peranannya di bandingkan dengan yang lainnya, seperti filsafat, kalam, ataupun tasawuf yang bersifat spekulatif dan kontemplatif.

Misalnya, N. J. Coulson (1964:37-38) mengatakan pada zaman pemerintahan Abbasiyah ada kebutuhan penguasa untuk mengatur kharräj (pajak tanah yang dibebankan kepada nonmuslim di wilayah Islam), mendorong Harun al-Rasyid (786-809 M) meminta Abu Yusuf (w. 799 M) -hakim Abbasiyah waktu itu- untuk menulis buku panduan tentang pajak non-muslim yang di beri nama kitäb al-kharräj, buku hukum positif tertua dalam khazanah keilmuan Islam. Oleh karena itu, sebenarnya pun fiqih lahir sesuai dengan kebutuhan masyarakat zamannya, dan dari sanalah, selain kedua alasan di atas, fiqih dianggap sebagai ilmu (paling)

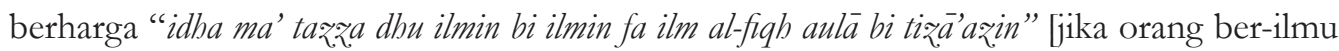
mulia lantaran ilmunya, maka ilmu fiqih membuatnya lebih mulia].

Maka, tak mengherankan jika doktrin tentang fiqih di atas membawa sense of graviti (rasa daya tarik) yang istimewa bagi sejumlah intelektual muslim dari waktu ke waktu untuk mengkaji dan mengembangkan ilmu ini. Berderet kitab-kitab kuning (the yellow themes, kutub al-safrah) dan berjilid-jilid kitab fiqih adalah bukti nyata adanya ketertarikan doktrin tersebut. Padahal semua itu hasil dari pengamatan ayat al-Qur'an yang menurut Fazlur Rahman (2000: 91), tak seberapa jumlahnya. Syaikh Tantawi Jauhari dalam tafsirnya menyebutkan hanya ada 150 ayat yang terkait dengan fiqih. 
Meski demikian halnya, pada prinsipnya fiqih harus bermuara pada prioritas pencapaian hukum (maqāsid asy-syari’ah). Di antara pencapaian hukum paling fundamental adalah tercapainya keadilan subtantif, bukan semata sesuai dengan aspek legalitas formal. Makanya, Abu Amenah Bilal Philips (1990: 44), menghimbau agar dalam legislasi fiqih perlu diprioritaskan beberapa prinsip,yakni: removal of difficulty (menghilangkan kesulitan), reduction of religious obligations (meminimalisir beban keagamaan), realization of public welfare (merealisasikan kesejahteraan umum) dan realization of universal justice (merealisasikan keadilan universal). Paradigma fiqih semacam inilah yang hendaknya dirumuskan kembali di era modern.

Namun, anjuran ini hampir-hampir (untuk sebagian wilayah) masih mengalami jalan buntu di level grass root dalam wilayah praksis. Karena pemikiran fiqih enggan memperbaiki metodologi berpikirnya. Egoisme mazhab, sekte-sekte atau golongan dan organisasi masih terhitung cukup tinggi, untuk itu, solusi yang harus diambil adalah membuka diri untuk perbaikan metodologi berpikir. Hal itu merupakan syarat mutlak untuk menyempurnakan cara dan metode berpikir keagamaan Islam yang baru.

Dengan demikian, dalam membaca fiqih tidak cukup dengan pembacaan parsial, tetapi harus dengan pembacaan komprehensif. Pembacaan komprehensif ini tidak hanya dilakukan pada kitab fiqih an sich, tetapi mencakup seluruh faktor dan melibatkan disiplin keilmuan modern. Meminjam istilah Jasser Auda (2008: xxv), fiqih tidak bersifat singgle entity, melainkan integrated entities. Jika ingin beranjak dari tradisi keilmuan yang lama. Sehingga rangkaian dari proses tasyri' adalah produk fiqih yang dapat dirasakan kesegarannya bagi umat manusia. Mengenai hal itu selengkapnya kita simak kata-kata Jasser Auda:

“...Without incorporating relevant ideas from other diciplines, research in the fundamental theory of Islamic law will remain within the limits of traditional literature and its manuscripts, and Islamic law will continue to be largely "outdated" in its theoretical basis and practical outcomes. The relevance and need for a multidiciplinary approach to fundamental of Islamic law is one of the argument of this book....Analogical reasoning (qiy $\hat{a}$ s) is another source of legislation that was reinterpreted from its traditional deduktive structure [considering a single case mentioned in the script as a basis for judgement for a new case] to a form of abduction [considering the largest possible number of cases that are related to the topic and deducing general guidelines for judgement]. A number of usul revisionists called this new method of qiyas, wide analogy". 
ljtihad: Jurnal Wacana Hukum Islam dan Kemanusiaan, Volume 18, No. 1, Juni 2018: 81-98

Maka, fiqih klasik hanya cocok pada zamannya dan tidak harus diikuti begitu saja sekarang ini tanpa diiringi pertanyaan yang kritis. Zaman telah berubah. Pendidikan telah mengubah segalanya, yang tentu saja berakibat pada perubahan muatan pengalaman dan penghayatan terhadap pemikiran fiqih. Oleh sebab itu, tidak bisa dipungkiri apabila rumusan fiqih juga dituntut untuk berubah dan berbeda dari rumusan fiqih klasik. Seperti yang dirumuskan Muhammad Syahrur, Mahmoud Mohemmed Thaha, Fazlur Rahman, Abdullah Saeed, M. Arkoun, Khaled Abou el-Fadl, M. Abid al-Jabiri dan yang lainnya. Mereka tidak mau lagi terjebak pada permasalahan fiqih klasik yang cenderung tekstualis. Mereka, berupaya menyentuh kebutuhan zaman yang dihadapi saat ini, yakni permasalahan kemanusiaan modern.

Sejurus dengan itu, sebelumnya Abu Ishaq ash-Shatibi (Juz II: 6) pernah menandaskan, bahwa Tuhan mendesain hukum-hukumnya tak lain demi terciptanya maslahah bagi manusia, baik di dunia maupun di akhirat (sa'ádatuddàrain). Contoh kongkrit dari bentuk maslahah ini menurut al-Shatibi (Juz II: 8-12), al-Ghazali (Juz I: 286), adalah pengayoman terhadap lima prinsip dasar (al-mabādi al-khams), yang menjadi cita-cita Islam (maqāsid asy-syarìah), di mana Islam hadir untuk melindunginya. Yakni, perlindungan agama (bifz\} ad-din), perlindungan

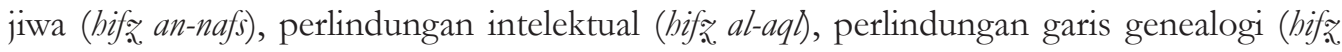
an-nash), perlindungan properti (bif z, al-mā̄).

Rumusan maqāsid ini memberikan pemahaman bahwa Islam tidak mengkhususkan peranannya hanya dalam aspek penyembahan kepada Allah (dogmatis-tanqifi), serangkaian perintah dan larangan an sich, yang tidak dapat langsung dipahami nilai aksiologisnya. Namun, juga mencakup semua aspek hajat hidup manusia yang terangkum dalam lima pilar dasar di atas yang bermuara pada satu dasar utama yang bernama maslahah, kebaikan umum (buman welfare). Karena itu, lima prisp ini bersifat universal.

\section{Diskursus bea cukai: Upaya penyatuan nilai fiqih dengan hukum negara}

Fiqih sebagai fakta sosial merupakan sebuah peristiwa yang bersumber dari manusia, baik sebagai perilaku pribadi maupun sebagai perilaku sebuah komunitas. Sejak perjalanannya sampai sekarang ini, fiqih mengalami pergulatan yang cukup intensif seiring dengan dinamika masyarakat itu sendiri. Apalagi di Indonesia yang mayoritas penduduknya Islam, namun, 
negara bukan beridiologi keislaman. Sudah barang tentu menyebabkan fiqih vis a vis negara atau dapat terjadinya dua kemungkinan, baik resistensi ataupun apresiasi.

Misalnya, masalah wanita jadi presiden, seperti isu politik ketika Megawati calon presiden, masalah demokrasi, masalah pemimpin non muslim di Indonesia seperti (kasus Ahok) sekarang ini yang sedang ramai di bicarakan publik. Semua itu selalu berhadapan antara fiqih dengan negara. Ada juga misalnya berkaitan dengan aktivitas sosial ekonomi, yang berkaitan dengan jual beli barang selundupan. Dalam konteks Indonesia praktik semacam itu beresiko tapi disenangi. Dimusuhi namun digemari. Praktik penyelundupan barang semacam itu bisa kita lihat di Batam, pelabuhan tanjung perak Surabaya, pelabuhan ketapang Banyuwangi, dan sebagainya. Di sana bongkar muat barang selundupan ramai dilakukan. Khususnya barang-barang elektronik dari luar negeri. Lalu, bagaimana mazhab fiqih dan mazhab negara (Undang-undang) memandang aktivitas jual beli tersebut?

Jika kita merujuk pada ketentuan dalam fiqih muamalah, maka tidak memerlukan dalil teks secara terinci dan mendetail, hukum yang sering digunakan dalam menikapi kasus seperti ini adalah الأصل فن المعاملة الإباحة hukum asal tindakan ber-mu'amalah adalah boleh dilakukan]. Dengan mengacu pada kaidah ini maka dalam persoalan mu'amalah atau interaksi sosial sehari hari kita bebas mengembangkannya sejauh tidak bertentangan dengan teks-teks umum yang telah menggariskannya. Maka dari itu, kita bebas melakukan transaksi apapun tidak terkecuali aktivitas jual beli. Karena dalam jual beli yang terpenting dilakukan dengan berprinsip saling legawa [antarädin minkum], bukan transaksi dengan cara batil pemahaman ini dibangun bertendensi pada al-Qur'an (An-Nisa, [4]: 29).

Secara moralitas jual beli sebenarnya tidak hanya dilakukan sebatas memenuhi keinginan para pelakunya untuk memperoleh keuntungan, akan tetapi harus dilakukan sebagai bagian untuk mendapatkan ridla Allah. Kasus jual beli barang di atas, jika kita merujuk kepada konsep jual beli dalam kajian fiqih mu'amalah maka niscaya tidak diketemukan syarat adanya bea (usyr) cukai (maks). Jual beli dalam fiqih mu'amalah yang penting adalah terpenuhinya struktur akad (syarat rukun), yakni, di antara rukun jual beli antara lain: ‘äqidain (penjual dan pembeli), ma'qüd 'alaih (barang dagangan [mabi] dan alat pembayaran [taman]) dan sighah (ijab dan qabul). Jika semua unsur tersebut sudah terpenuhi maka, dalam transaksi jual beli dianggap sah. 
ljtihad: Jurnal Wacana Hukum Islam dan Kemanusiaan, Volume 18, No. 1, Juni 2018: 81-98

Kembali pada kenyataan tentang apa dan bagaimana memahami hukum jual beli barang selundupan di atas, fiqih mu'amalah sudah menandaskan bahwa jual beli hanya bisa dikatakan sah bila mana terpenuhinya rukum di atas. Maka dalam perspektif hukum ekonomi Islam jual beli barang tersebut dianggap boleh, namun bertentangan dengan maslahat. Karena orientasi paling fundamental dalam hukum Islam adalah kemaslahatan, namun tidak hanya maslahat personal an sich. Melainkan kemaslahatan yang bersifat universal (ammah). Masih ada maslahah yang lebih besar ketimbang hanya memikirkan kemaslahatan indiviual, dalam hal ini terdapat kepentingan negara [apalagi negara berkembang] untuk melakukan penguatan ekonomi dan pembangunan.

Oleh karena itu, diperlukan masukan dana guna pembangunan negara [Indonesia] agar lebih mandiri dan lebih khusus lagi dapat mensejahterakan rakyatnya. Kesejahteraan dan perbaikan hidup setiap warganya merupakan aspek sangat penting dalam sebuah negeri. Konsekuensinya, negara harus berupaya keras turut andil dalam meminimalisir kemiskinan dan mewujudkan perekonomian yang stabil salah satunya dapat menambah khas negara dengan cara menetapkan bea cukai bagi barang luar negeri yang masuk ke Indonesia maupun sebaliknya.

Untuk mendukung upaya peningkatan dan pengembangan perekonomian nasional yang berkaitan dengan perdagangan global. Kepabean hadir sebagai sesuatu yang berhubungan dengan pengawasan atas lalu lintas barang yang masuk dan keluar daerah pabean dan pemungutan bea masuk dan bea keluar. Pengertian tersebut menegaskan bahwa UU No. 17 tahun 2006 tentang perubahan atas UU No. 10 tahun 1995 tentang institusi bea dan cukai berwenang dalam melakukan pengawasan atas barang ekspor dan impor dalam pemungutan bea masuk dan bea keluar.

Dalam hukum negara Indonesia, semua barang-barang dagangan yang masuk maupun keluar berdasarkan Undang-undang tersebut harus dikenai pajak bea cukai. Kebijakan pemerintah mengatur perdagangan antar bangsa memungut tarif retribusi pajak, sesungguhnya juga dalam rangka menstabilkan harga dalam negeri. Kalau saja misalnya, sekarang tidak dikenai pajak bea dan cukai niscaya dalam negeri dijejali produk-produk yang berasal dari luar negeri. Para investor pemodal besar dalam maupun luar negeri tertawa (merasa) merdeka dan kuat karena bebas (bea cukai) impor ekspor barang. Sedangkat rakyat 
menjerit akan tergilas karena ketidakmampuannya dalam persaingan.

Kita bisa lihat sekarang, meskipun dikenai retribusi saja, di negeri ini masih menjamur barang-banrang luar negeri, mulai dari semua jenis merek mobil, sepeda motor, hand phone, peralatan rumah tangga dan lainnya. Melihat kondisi semacam itu, jika hal ini tidak ditanggulangi dengan melakukan penarikan retribusi, maka negara akan rugi besar, apalagi Indonesia saat ini masih membutuhkan banyak anggaran untuk melakukan pembangunan. Oleh karena itu, tindakan pemerintah memberlakukan penarikan retribusi bea cukai adalah bentuk dari tindakan preventif, menutup kooptasi sarana (sadd adh-dharä ‘) yang mengarah kepada ketidak-stabilan harga domestik. Itu artinya penarikan bea cukai dapat membawa pada kemaslahatan (jalb al-masălih) bagi negara dan rakyat berupa pengayoman terhadap properti (bifzal-māi).

Meskipun demikian, setidaknya ada dua syarat yang harus dipenuhi dalam menetapkan retribusi pertama, janganlah dikenakan atas barang yang menjadi kepentingan rakyat banyak. Kalau mau dikenakan, kenakanlah atas barang-barang yang secara substansial tidak terlalu penting bagi kehidupan manusia dan hanya mengena pada kepentingan atau bahkan selera kalangan tertentu saja. Yang kedua, hasil pungutan cukai pun harus dapat dipertanggung jawabkan secara moral dan hukum bahwa penggunaannya bagi kepentingan rakyat banyak.

Praktik semacam itu dalam Islam disebut 'ushr yang secara harfiah artinya sepersepuluh, karena pada zaman itu terif masuk ini rata-rata memang 10\%. Pada dasarnya menurut Masdar farid Mas'udi (2009: 221), Islam tidak merekomendasikan pungutan jahiliyah jenis ini yang memang mentradisi dimana-mana. Setidaknya ada dua alasan, yang pertama, karena tidak jelas tas\}arruf (penggunaan)nya, selain untuk para centeng berkuasa. Dan kedua, pungutan seperti itu jelas menciptakan ekonomi harga tinggi dengan naiknya harga barang yang menjadi sasarannya, yang memberatkan masyarakat. Oleh karena itu, praktik penarikan bea cukai dilarang dengan merujuk pada sebuah riwayat :

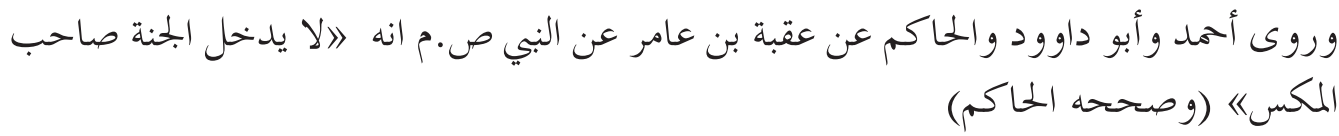

Artinya: Tidaklah masuk surga bagi (penguasa) yang memungut cukai. 'Illat pelarangan mengambil bea cukai dalam Islam sesungguhnya hanya dipengaruhi dua faktor di atas yang bersifat ahistoris. 
ljtihad: Jurnal Wacana Hukum Islam dan Kemanusiaan, Volume 18, No. 1, Juni 2018: 81-98

Namun, setelah 'illat pelarangan tidak ada maka pengambilan bea cukai bisa dibenarkan, karena berangkat dari kaidah “al-hukm yadüru ma’a al-illati wujüdan wa adaman”. Oleh karena itu menyikapi permasalahan di atas, alasan poin pertama dengan kontrol manajemen dan sosial melalui perundang-undangan yang ketat. Meskipun alasan kedua tidak bisa dikatakan terwujud jika tidak dikatakan sulit.

Indonesia sebagai negara yang masih berstatus berkembang (membutuhkan santunan negara lain) sudah barang tentu jika menetapkan tarif bea cukai kepada importir dan eksportir untuk menambah khas negara merupakan suatu yang niscaya, di samping karena alasan pertama, upaya pencegahan masuknya barang luar negeri secara besar-besaran akan mengakibatkan barang-barang produksi dalam negeri akan kewalahan karena tidak mampu bersaing dengan kualitas barang bagus tapi harga terjangkau maka kedua, dengan sendirinya produksi dalam negeri baik agrobisnis (pertanian, perkebunan) maupun UMKM akan tergilas atau paling banter hanya bisa bertahan jalan ditempat. Jika ini terjadi ketiga, pengangguran masyarakat pribumi merajalela yang berujung pada kemelaratan. Di sinilah peran vital pemerintah untuk mengatur bea cukai. Karena menerapkan hukum bea cukai di Indonesia berarti sama halnya درء المفاسد مقدم على جلب المصالح dengan menolak kebangkrutan, sebagaimana kaidah [menolak kebangkrutan itu lebih didahulukan daripada mendatangkan kemaslahatan].

Jadi, pokok dari pemberlakukan bea cukai di Indonesia merupakan wujud kongkrit dari bentuk maslahah adalah pengayoman terhadap lima prinsip dasar (al-mabädi' al-khams), yang menjadi cita-cita Islam (maqāsid asy-syari’ah), di mana Islam hadir untuk melindunginya. Yakni,

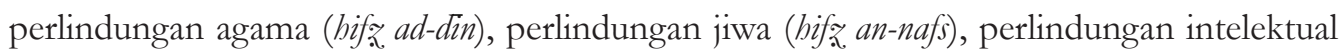
(bifzal-'aq), perlindungan garis genealogi (bifž an-nasl), perlindungan properti (bifzal-māl).

Kenyataannya khalifah Umar bin Khattab belakangan terpaksa menolelir dihidupkan kembali karena barang-barang komoditi yang di ekspor dari negaranya ternyata tetap saja dikenakan beban usyroleh negara lain yang jadi tujuannya, (Abdul Wahab Khallaf, 1994:156). Dengan kata lain, karena dipungut maka Umar pun memungut. Kalau saja ketika itu sudah ada hubungan bilateral atau multilateral yang memungkinkan beban ushr (bea masuk) bisa dibicarakan antar negara yang saling impor, kata Masdar (2009: 222), tentulah Umar akan mengusulkan supaya bea masuk ditiadakan, dan jadilah perdagangan antar negara berjalan dalam sistem pasar bebas seperti yang kini diinginkan oleh banyak orang. 


\section{Maslahah kunci fiqih perdagangan bebas}

Sejak kali pertama didengungkan ide trade market banyak negara pasang kuda-kuda menghadapi pasar bebas tersebut, tidak terkecuali Indonesia. Antara siap dan tidak siap, melihat kenyataan yang ada, Indonesia sendiri sebenarnya belum siap untuk menerapkan pasar bebas. Baik dari buman resources maupun produk-produk yang dihasilkan. Jika demikian, adanya pasar bebas tersebut akan mengakibatkan Indonesia menjadi negara jajahan produk luar negeri. Maka dalam konteks ini jika Indonesia (dan sebagian negara berkembang lainnya) memaksakan memasang diri membuka kran perdangan bebas berarti menggali kuburannya sendiri.

Perdagangan bebas dibentuk dalam beberapa blok perdagangan seperti Association of Southeast Asian Nations (ASEAN), North American Free Trade Agreement (NAFTA). Tepat tanggal 1 Januari 2010 mulai diberlakukan Free Trade Agreement(FTA/Perjanjian Perdagangan Bebas) ASEAN-China. Negara-begara ASEAN yang termasuk yaitu: Indonesia, malaysia, Singapura, Brunai, Vietnam, Filiphina, Kamboja, Laos, Thailand, dan Myanmar. Adapun hasil kesepakatannya yaitu bea masuk produk manufaktur China ke ASEAN, termasuk Indonesia, ditetapkan maksimal 5 persen, sedangkan di sektor pertanian 0 persen tanpa pajak sama sekali.

Perdagangan bebas adalah suatu konsep ekonomi yang mengacu kepada Harmonized Commodity Description and Coding System (HS) dengan ketentuan penjualan produk antar negara tanpa pajak ekspor-impor atau hambatan perdagangan lainnya. Perdagangan bebas dapat juga didefinisikan sebagai tidak adanya hambatan buatan (hambatan yang diterapkan pemerintah) dalam perdagangan antar individual-individual dan perusahaan-perusahaan yang berada di negara yang berbeda (http://id.wikipedia.org/wiki/ diakses 08 April 2017).

Sebenarnya, perdagangan bebas dan pasar bebas merupakan strategi Amerika untuk menguasai ekonomi dunia, tidak hanya negara-negara berkembang dan miskin tetapi juga negara-negara maju yang menjadi pesaing Amerika akan dilibas dan digulung ke dalam genggaman Amerika. Tidak lain perdagangan bebas dan pasar bebas hanyalah merupakan metode penjajahan gaya baru, yakni new imperialism di bidang ekonomi. Jelas perdagangan bebas dan pasar bebas sangat berbahaya terutama bagi dunia ketiga.

Meskipun demikian, Kiai Ali Yafie sangat respek dengan perdagangan bebas ini, ia mengatakan bahwa: "prinsip dasar perdagangan Islam adalah adanya unsur kebebasan dalam melakukan transaksi dengan mengindahkan kerelaan kedua belah pihak. Pada zaman 
ljtihad: Jurnal Wacana Hukum Islam dan Kemanusiaan, Volume 18, No. 1, Juni 2018: 81-98

Rasulullah, perdagangan yang dilakukan selalu didasarkan pada prinsif kebebasan" (Ali Yafie, 2003: 1). Memang demikian adanya, fiqih ekonomi Islam mempunyai progresifitas yang sangat luar biasa maju. Namun, yang menjadi persoalan adalah jika negara masih berstatus negara berkembang (membutuhkan santunan negara lain), belum mapan secara ekonomi, dan belum mampu menghasilkan produk unggulan yang memiliki daya saing international, akan banyak memunculkan kerugian bagi negara. Maka ibarat sedang berjalan, "negara maju menggunakan mobil dan negara berkembang masih jalan kaki”.

Sehingga cita-cita syari'ah belum dapat terwujud dengan sempurna. Karena seharusnya dalam menetapkan suatu kebijakan (hukum) harus melihat realitas, dalam hal ini Ahmad al-Raisyuni (2012: 59) bertutur: "là budda labu min an yaküna 'ärifan khabiran basiran bi al-wäqi' alladbi fỉhi yajtabidu wa fî̉i yufti”. Artinya bahwa, seorang mujtahid (pemangku kebijakan) harus melengkapi diri dengan pengetahuan yang terkait realitas seperti antropologi, sosiologi, politik, ekonomi dan lain-lain. Tanpa ilmu bantu tersebut, alih-alih memberikan maslahat, boleh jadi mengikuti pasar bebas (tanpa ada kesiapan matang) menimbulkan mafsadat bagi masyarakat. metode tersebut dalam ilmu ușul al-fiqh biasa disebut dengan tahqiq al-manăt.

Gejolak pasar bebas yang muncul dari rahim kapitalis, dengan pranata pasar bebasnya, yang diterapkan di Amerika Serikat ternyata gagal dalam mewujudkan keadilan sosial (A. Sonny Keraf, 1996: 262-272). Kegagalan Pasar bebas tersebut menuai kritik pedas dari seorang filosof kenamaan asal negeri Pamansam, John Rawls. ia menilai mekanisme pasar bebas gagal berfungsi secara baik. John Rawls (1997: 72) mengatakan:

"Dalam sistem kebebasan kodrati..(memang ada) kesamaan kesempatan yang formal, dalam pengertian bahwa semua orang paling kurang mempunyai hak legal yang sama untuk akses pada semua kedudukan sosial yang menguntungkan. Akan tetapi karena tidak ada usaha untuk mempertahankan suatu kesamaan, atau kemiripan, kondisi sosial...distribusi awal dari aset-aset untuk suatu periode tertentu sangat dipengaruhi oleh keadaan alamiah dan sosial yang kebetulan. Distribusi pendapatan dan kemakmuran yang ada, demikian dapat dikatakan, merupakan akibat komulatif dari distribusi aset alamiah, yakni bakat dan kemampuan alamiah, sebelum distribusi pasar bebas".

Karena itu, pasar bebas justru menimbulkan ketidakadilan. Paling jelas terletak pada sistem kebebasan kodrati, menurut Rawls (1997: 72), adalah bahwa sistem ini mengizinkan pembagian kekayaan dipengaruhi secara tidak tepat oleh kondisi-kondisi alamiah dan sosial 


\section{Paradigma baru fiqih perdagangan bebas: Dialektika ulūm al-đin dan hukum negara (Akmal Bashori)}

yang kebeulan, yang dari sudut pandang moral demikian sewenang-wenang. Keadaan seperti ini justru akan menimbulkan distribusi tidak adil.

Uraian Rawls di atas menggambarkan betapa pasar bebas sebenarnya akan melahirkan kepincangan karena perbedaan bakat dan kemampuan alamiah antara orang satu dengan lainnya. Negara satu dengan negara lain. Negara berkembang tentu berbeda dengan negara maju dalam segala kemampuan baik modal (capital) maupun modal sosial. Oleh sebab itu, pasar bebas secara fundamental sesungguhnya sangat bertentangan dengan prinsip Islam yang menghendaki adanya pemerataan dalam distribusi ekonomi. Sehingga terwujud kemaslahatan umum (public welfare).

Cita kemaslahatan ini harus menjadi dasar dan substansi dari seluruh aktivitas kebijakan (hukum) yang diambil. Kalkulasi kemaslahatan sekaligus kemafsadatan itu harus ada dalam pikiran para pemangku kebijakan dan ahli fiqih ketika hendak menerapkan hukum atau menegakkan sebuah undang-undang. Jika acuan penerapan kebijakan tersebut adalah dosis kemaslahatan dan kemafsadatan yang ditimbulkannya, maka boleh jadi para ulama dan umara menerapkan hukum A di satu tempat dan menerapkan hukum B di tempat lain. Sebab, tidak mustahil bahwa suatu bernilai maslahat di satu tempat dan menimbulkan kemafsadatan di tempat lain.

Begitu juga sangat mungkin terjadi, dahulu penerapan sebuah hukum menimbulkan kemafsadatan, tatapi sekarang jika menerapkannya menimbulkan kemaslahatan (contoh lihat bagian sebelumnya tentang kebijakan Umar bin Khattab tentang bea cukai). Karena itu, perubahan-perubahan kebijakan hukum sangat mungkin terjadi seiring dengan perubahan situasi dan kondisi masyarakat, sebagaimana adagium yang disampaikan Ibn Qayyim alJauziyah (III: 3); "taghayyur al-fatāwā wa ihtiläfuhà bi hasabi taghayyur al-azminah wa al-amkinah wa al-ạ̣wāl wa al-niyyah wa al-'awāid'. Demikian pentingnya kemaslahatan tersebut, maka kemaslahatan yang tidak diafirmasi oleh al-Qur'an dan Hadis pun bisa dijadikan sebagai sumber hukum. Tentu dengan catatan, kemaslahatan itu tidak dinegasikan oleh nas al-Qur'an dan Hadis.

Oleh karena itu, yang perlu dipersiapkan oleh negara (Indonesia) agar siap menghadapi era baru perdagangan bebas, menurut Abu Hasan al-Mawardi (1987: 43) adalah negara harus membuat areal produktif yang menjamin pertumbuhan ekonomi sehingga dapat 
ljtihad: Jurnal Wacana Hukum Islam dan Kemanusiaan, Volume 18, No. 1, Juni 2018: 81-98

dinikmati oleh segenap lapisan masyarakat. Karena wilayah produktif merupakan salah satu faktor yang membawa kepada kemaslahatan dunia, dan bisa menciptakan stabilitas di segala bidang. Menurutnya (1987: 45) produktifitas tersebut terbagi atas dua poin; produktifitas jasa dan produktifitas sumber daya alam. Produksi jasa dan dunia usaha merupakan efek dari produktifitas sumber daya alam. Sedangkan produktifitas sumber alam adalah anugrah Ilahi yang harus dikelola secara efisien.

Kedua produktifitas menurut al-Mawardi di atas, dapat dijadikan sebagai modal dalam menghadapi pedagangan bebas. Namun, kita harus mencatat bahwa sebenarnya pesan al-Mawardi adalah agar masyarakat (Indonesia) menggunakan kreatifitasnya untuk memaksimalkan potensi alam yang ada di nusantara. Seperti, batu bara, minyak bumi, kelapa sawit, pertambangan emas (freeport), padi, gandum, dan hasil sumber daya alam lainnya.

Jika sudah mempunyai modal di atas, langkah selanjutnya tinggal menyusun konsep kebebasan pasar yang dapat dibenarkan jika dibangun atas prinsip-prinsip sebagai berikut:

1) Saling legawa, yakni segala transaksi yang dilakukan haruslah atas dasar kerelaan antara masing-masing pihak (freedom contract);

2) Persaingan sehat (fair competition). Mekanisme pasar akan terhambat bekerja jika terjadi penimbunan (ibtikar) atau monopoli. Monopoli dapat diartikan setiap barang yang penahanannya akan membahayakan konsumen atau orang banyak.

3) Kejujuran (bonesty), kejujuran merupakan pilar yang sangat penting dalam Islam, sebab kejujuran adalah nama lain dari kebenaran itu sendiri. Islam melarang tegas melakukan kebohongan dan penipuan dalam bentuk apapun. Sebab, nilai kebenaran ini akan berdampak langsung kepada para pihak yang melakukan transaksi dalam perdagangan dan masyarakat secara luas.

4) Keterbukaan (transparancy) serta keadilan (justice). Pelaksanaan prinsip ini adalah transaksi yang dilakukan dituntut untuk berlaku benar dalam pengungkapan kehendak dan keadaan yang sesungguhnya.

5) Pemerataan harta. Tidak hanya berhenti di satu titik.

Poin di atas dapat diambil pengertian bahwa dalam pasar bebas dituntut "keadilan harga" dan dapat terwujud jika pelaku ekonomi bisnis dapat bertindak saling rela, bersaing secara sehat, jujur, dan tidak melakukan kecurangan dalam transaksinya. Namun jika tidak, maka 
intervensi negara sangat diperlukan demi menjamin keadilan harga di pasar (masyarakat), sebagimana yang dilakukan Nabi SAW. terhadap pelaku-pelaku ekonomi bisnis yang bertindak curang. Oleh karena itu negara atau pemerintah sangat dibutuhkan keterlibatannya dalam pasar sebagai supervisor dan pengontrol.

Dalam terminolog fiqih, kewenangan negara atau presiden yang demikian ini dapat diwakilkan oleh kementrian al-hisbah, yakni sebuah kementrian berwenang mengawasi para pedagang dan professional untuk mencegah kecurangan dalam pekerjaan, timbangan, kualitas barang, dan menjaga agar harga selalu konstan (A. Islahi, 1997: 42), atau dalam bahasa yang lebih umum, untuk menegakkan amar ma'ruf nabi munkar (Ibn Khaldun, 1961: 225, Abu Hasan al-Mawardi, 1973: 240). Al-hisbah dalam bidang ekomomi bisnis inilah yang berfungsi untuk melakukan pengawasan dan menindak para pelaku ekonomi bisnis jika bertindak curang dalam usaha dagangnya. Pejabat yang bertanggung jawab atas lembaga hisbah disebut mubtasib.

Hal itu merupakan tanggung jawab negara terhadap pengawasan mekanisme pasar (terlebih adanya pasar bebas). Negara berwenang untuk mengntrol harga atau menetapkan besarnya upah pekerja demi kepentingan publik. Dalam konteks Indonesia, negara harus memberikan kebijakan harga khusus, terlebih bagi para importir -yang mendatangkan produk luar negeri- agar barang lokal tidak kalah saing sehingga produk dalam negeri tetap mempunyai harga stabil. Bila perlu harus dilakukan penetapan harga oleh negara mengenai produk dari luar dalam rangka memproteksi produk dalam negeri. Tetapi menurut A. Islahi (1997: 230), penetapan harga tidak boleh sewenang-wenang, harus ditetapkan melalui musyawarah, negosiasi dan pembahasan melalui konsumen dan produsen. Tujuannya agar harga bisa diterima semua pihak dan akibat buruk dari penetapan harga itu harus dihindari.

Adapun al-hisbah pada dasarnya mempunyai beberapa fungsi yakni: pertama, fungsi ekonomi. Dalam mengawasi aktivitas pasar, tugas mubtasib terdiri dari: (a) pengawasan harga, ukuran, takaran dan timbangan. Untuk mengawasinya mubtasib dapat memerintahkan setiap pedagang untuk menempel daftar harga (price list) yang berlaku; (b) mengawasi jual beli terlarang. Mubtasib bertugas mengawasi jual beli barang dan jasa yang dilarang syari'at baik terlarang karena zatnya maupun terlarang karena jual beli tersebut menggunakan akad yang menyimpang dari ajaran Islam; (c) mengawasi standar kehalalan, kesehatan dan kebersihan suatu komoditas. Mubtasib harus melakukan quality control atas barang-barang yang beredar 
ljtihad: Jurnal Wacana Hukum Islam dan Kemanusiaan, Volume 18, No. 1, Juni 2018: 81-98

di pasar. (d) pengaturan pasar. (e) melakukan intervensi pasar. Mubtasib adalah petugas pemerintah yang memiliki otoritas melakukan intervensi pasar dan harga dalam keadaan dan alasan-alasan tertentu, misalnya tingginya harga-harga yang diakibatkan kelangkaan barang karena penimbunan barang oleh para spekulan. (f) memberikan hukuman terhadap pelaku pelanggaran. Mubtasib bertugas mencegah kemunkaran dan pelanggaran berbagai ketentuan di pasar dan memberikan sanksi yang tepat serta tindakan korektif. Ketika para pembeli atau pedagang melakukan tindakan pelanggara, misalnya menipu, curang, ihtikar, transaksi gharar, riba dan jual beli terlarang lainnya yang berakibat poda rusaknya stabilitas pasar.

Kedua, fungsi sosial. Fungsi sosial institusi hisbah adalah mewujudkan keadilan sosial dan keadilan distributif dalam masyarakat, lewat tugasnya memberikan informasi kepada para pedagang dan konsumen, memberikan kesempatan yang sama kepada setiap orang dan menghilangkan penguasaan sepihak jalur produksi dan distribusi di pasar, menghilangkan distorsi pasar dan melakukan intervensi pasar dalam keadaan- keadaan tertentu, sehingga dapat memperkecil ketimpangan distribusi di pasar dengan menciptakan harga yang adil. Ketiga, fungsi moral. Institusi hisbah adalah lembaga pengawas berlangsungnya moral dan akhlak Islami dalam berbagai transaksi dan perilaku konsumen dan produsen di pasar. Tugasnya adalah mewujudkan perekonomian yang bermoral. Pada tataran yang lebih luas tugas dari hisbah adalah amar ma'ruf naby munkar. Pasar merupakan sasaran utama pengawasan hisbah karena di sana sering terjadi penipuan, kecurangan, ihtikar, riba, pemaksaan dan kesewenang-wenangan.

Di Indonesia hendaknya mengacu pada lembaga hisbah di atas, atau boleh jadi melalui Kementerian perindustrian dan perdagangan lebih ketat dalam mengawasi perdagangan, serta menindak tegas negara-negara asing yang melakukan hubungan dagang di Indonesia, tapi tidak mengindahkan totokromo, undang-undang yang dikeluarkan pemerintah Indonesia. Semua itu demi kemaslahatan rakyat. Maka pemangku kebijakan harus bijak dalam memutuskan kebijakannya "tasarruf al-imām 'alà ar-raiyyati manūtun bi al-maslahab". Allahu 'alam

\section{Penutup}

Indonesia merupakan negara berkembang yang masih membutuhkan santunan dari negara lain. Oleh karena itu dengan adanya bea cukai negara mendapatkan pemasukan dari investor 
yang impor maupun ekspor produknya. Dengan adanya wacana pasar bebas, melihat kenyataan yang ada Indonesia belum mampu mengikutinya. Indonesia harus berbenah menyiapkan produk unggulan yang mempunyai daya saing International.

Pesan fiqih, toh, jika Indonesia terpaksa harus ikut serta dalam pasar bebas, boleh-boleh saja, akan tetapi fiqih memberikan rambu-rambu supaya negara tidak mengikuti tanpa dasar yang matang. Negara harus mempersiapkan sumber daya insani agar lebih kreatif dalam produktifitasnya, dan pandai-pandai memanfaatkan sumberdaya alam. Di samping negara tentunya harus melihat realitas masyarakat sehingga tidak menimbulkan ketidak adilan harga yang berujung pada kebangkrutan masyarakat dan negara pun ikut menanggungnya. Sehingga keputusan negara hendaknya bermuara pada maslahat, melalui tiga pemenuhan dharüriyāt, häjiyat dan tabsiniyyāt.

\section{Daftar pustaka}

Ash-Shatibi, Abu Ishaq Muhammad. Al-Muwäfaqāt fì Ușül al-Syarīah. Beirut: Dār ar-Rasyād al-Hadithah. Jilid. II, 1991.

Auda, Jasser. Maqashid Shari'ah as Philosophy of Islamic Law. London: IIIT, 2008.

Coulson, Noel J. A Historis of Islamic Law. Edinburg: University Press, 1964.

Ghazali, Abu Hamid al-. Al-Mustasfā min 'Ilm al-Ușūl, Beirut: Mu'assasah al-Risālah, tt. Jilid. I. Ibnu Khaldun. al-Muqaddimah. Beirut: Dar al-Fikr, 1961.

Islahi, A. A. Konsepsi Ekonomi Ibnu Taimiyah (terj). Anshari Thayib. Surabaya: Bina Ilmu, 1997. Jauhari, Thanthawi. Al-Jawāhir fî Tafsìr al-Qur'ān al-Karim. Beirut: Dar al-Fikr, 1923.

Jauziyyah, Ibn Qayyim al-. I'lam al-Muwaqqi’n An-Rabb Ālamin. Beirut: Dar al-Fikr. Jilid III, tt. Keraf, A. Sonny. Pasar Bebas, Keadilan, dan Peran Pemerintah: Telaah atas Etika Politik Ekonomi Adam Smith. Yogyakarta: kanisius, 1996.

Khallaf, Abdul Wahab. Politik Hukum Islam. (terj). Zaenudin Adnan. Yogyakarta: Tiara Wacana, 1994.

Mas’udi, Masdar Farid. Pajak Itu Zakat. Bandung: Mizan Pustaka, 2010.

Mawardi, Abu Hasan Basri asy-Shafi’i al-. al-Ahkēm al-Sultāniyah. Mesir: Mustafa al-Bāby al-Halaby, 1973.

Mawardi, Abu Hasan Basri asy-Shafi’i al-., Adab al-Dunyā wa ad-Din. Beirut: Maktabah al-Hayāt, 1987.

Philips, Abu Amenah Bilal. The Evolution of Fiqh. Riyadl: International Publishing House, 1990. 
ljtihad: Jurnal Wacana Hukum Islam dan Kemanusiaan, Volume 18, No. 1, Juni 2018: 81-98

Rahman, Fazlur. Islam. terj. Ahsin Mohammad. Bandung: Pustaka., 2000.

Raisyuni, Ahmad al-. Al--jtithäd: al-Nasss al-wäqi', al-Maslahah. Beirut: Asy-Syabakah Arabiyah li al-Abhāth wa al-Nashr, 2012.

Rawls, John. A Theory of Justice. Cet. XXII. Canbridge: The Balknap Press of Harvard University Press. 1997.

Yafie, Ali. Fiqib Perdagangan Bebas. Jakarta: Teraju, 2003. 